\title{
DISTRIBUTION OF AZOLLA FILICULOIDES LAM. (AZOLLACEAE) IN POLAND
}

\author{
EWA SZCZĘŚNIAK ${ }^{1}$, JAN BŁACHUTA ${ }^{2}$, MAREK KRUKOWSKI ${ }^{3}$, \\ JOANNA PICIŃSKA-FAŁTYNOWICZ ${ }^{2}$ \\ ${ }^{1}$ University of Wrocław, Institute of Plant Biology \\ Kanonia 6/8, 50-328 Wrocław, Poland \\ e-mail: ewaszcz@biol.uni.wroc.pl \\ 2 Institute of Meteorology and Water Management, \\ Parkowa 30, 61-616 Wrocław, Poland \\ ${ }^{3}$ Wrocław University of Environmental and Life Sciences, \\ Institute of Landscape Architecture \\ Grunwaldzka 24a, 50-363 Wrocław, Poland
}

(Received: July 15, 2009. Accepted: August 5, 2009)

\begin{abstract}
Azolla filiculoides has been an ephemeral plant in Poland since the end of the 20th century. In the last 15 years this species appeared in 5 locations in south-west Poland. Habitat and plants of two populations became destroyed, three other still exist. A. filiculoides occurs in eutrophic or even polluted water where it forms dense mats, up to $10 \mathrm{~cm}$ thick. It stays sterile and propagates only in a vegetative manner. Frost resistance of Lower Silesia populations is higher than reported so far; fern may winter and rebuild the population after frost reaching $22^{\circ} \mathrm{C}$. Size of the populations is changeable during the vegetation season. A. filiculoides occurs in water habitats and plant communities in which it substitutes Lemna minor.
\end{abstract}

KEY WORDS: Azolla filiculoides, invasive species, water ferns, Poland.

\section{INTRODUCTION}

The name Azolla comes from the Greek words "azo" to dry, and "ollymi" - to kill or to destroy, suggesting the death from drought. The monogeneric family Azollaceae consists of small, floating, not drought-tolerant fern species, found throughout the tropical and temperate zones of the world. The genus was included at first into family Salviniaceae due to seeming similarity, but phylogenetic relationship is distant and thus both families are considered as separate units.

The taxonomy of Azollaceae is problematic because of similarity of species, their main vegetative way of reproduction and high morphological variability. In temperate climate the most common is Azolla filiculoides Lam. Some pteridologists synonymize A. filiculoides and A. carolinia$n a$ (Valentine and Moore 1993). This classification was accepted by Mirek et al. (2002). The second classification presents A. filiculoides and A. caroliniana as two separate taxa. A. filiculoides is native to temperate and subtropical western zones of Central and North America where it reaches as far as Alaska. The more termophilous A. carolinia$n a$ is native to the eastern part of Central America (Lumpkin 1993).
Thorough research on the New World Azolla species was undertaken by Evrard and van Hove (2004). Based on the type specimen they revealed that A. microphylla and $A$. caroliniana are synonyms of the previously described $A$. filiculoides, moreover, ferns identified as such by most authors differ from their type specimen. The authors proposed that two species only exist in America: A. cristata Mettenius 1867 and A. filiculoides. Azolla cristata includes A. microphylla, A. mexicana and A. caroliniana, i.e. species with two-celled leaf trichomes and a tip in glochidia of massulae with more than 2 septae. Azolla filiculoides is a species with one-celled leaf trichomes and a tip in glochidia of massulae with up to 2 septae. Current synonyms of Azolla filiculoides Lam. are: A. arbuscula Desvaux, A. bonariensis Bertoloni, A. japonica Franch. et Sav, A. magellanica Willd., A. rubra R. Brown, A. filiculoides Lam. var. rubra (R. Brown) Strasb. and A. squamosa Molina.

Azolla was a genus native to Europe, which became extinct during the last Ice Age. Tertiary and Pleistocene stands of Azolla filiculoides were found also in Poland (Janczyk-Kopikowa 1977; Raniecka-Bobowska 1977). As a result of human activity it is currently a cosmopolitan plant occurring in South Africa, Asia, Australia, South-, Central- and North America, South-, West-, Central- and 
North Europe (Weber 2005; Hussner 2006). In South Africa and tropical Asia it is an invasive species (Weber 2005).

The species was introduced to Europe towards the end of the 19th century and the first observations were made in 1870s-1880s (Wilmanns 1976). It is impossible to construct a precise invasion map of Azolla filiculoides in Europe. The species was accidentally transported in ballast tanks of ships, in water with fry, or was introduced by human in other way. As a result it appeared independently in different places at almost the same time. Intentional or unintentional human activity is one of the most important spreading factor of $A$. filiculoides until now. Moreover, $A$. filiculoides is able to reach new regions by natural transporting vectors, e.g. waterfowls. The species spread out to nearly whole Europe. Near Poland, it has been found in Germany, where it is rather common (Weber 2005), in the Czech Republic (Kubát 2002) and Slovakia (Hrivnák et al. 2007). An ephemeral occurrence was noted in Lithuania in an exploited peat bog in 1946, later the Azolla population became extinct (Grudžinskas 2000).

\section{CHARACTERISTICS OF THE SPECIES}

Azolla filiculoides is a small free-floating fern up to 2.5-4 $\mathrm{cm}$ long, polygonal or triangular in shape (Lumpkin and Plucknett 1980). It floats on the water surface, rarely as individual plants or most often in mats, which can reach a thickness up to $20 \mathrm{~cm}$ (McConnachie et al. 2004).

Sporophytes consist of thin rhizomes, delicate palebrown roots up to $5 \mathrm{~cm}$ long and small leaves. Leaves are two-lobed, alternate and imbricate. Upper lobes of the leaves are usually green, covered by short, dense hair and are larger than the achlorophyllous lower lobes. When A. filiculoides plants are exposed to frost or strong sunlight they become red in color. In shade they remain green (Janes 1998a). Rhizomes are fragile and easily break into small fragments. Dispersal by small fragments of fragile sporophytes is the main way to increase the secondary range of the species. It spreads by zoo-, anemo- or hydrochory and, the most effective, anthropochory.

A. filiculoides is a heterosporous fern. It seems that sporulation of this species is regulated by the interacting effects of different habitat factors, mainly light intensity, photoperiod, temperature, $\mathrm{pH}$ and nutrient availability (Janes 1998b). Sporocarps appear on the lower leaf lobe. The species sporulates regularly in Great Britain (Janes 1998a, b); sporulating plants are also known from Germany (Hussner 2006).

Characteristic of the genus Azolla is the symbiotic relationship with the nitrogen-fixing blue-green alga Anabaena azollae. It is the only known mutualistic symbiosis between a pteridophyte and a diazotrophic prokaryote (Hove van and Lejeune 2002). Plants are never infected de novo: symbionts are transferred between generations as akinete inoculae. The symbiosis is sustained throughout the fern life cycle and its permanency suggests a parallel phylogenetic evolution of both partners (Watanabe and Hove van 1996; Carrapiço 2006). At the end of the 20th century other nitrogenfixing symbionts of Azolla were found, which are bacteria of the genus Azotobacter, and others (Carrapiço 1991).

The species grows best at $15-20^{\circ} \mathrm{C}$ and high irradiance (Janes 1998a; Watanabe and Berja 1983), even though
Wong et al. (1987) stated that optimum temperature for both nitrogen fixation and oxygen evolution is $25^{\circ} \mathrm{C}$. Azolla biomass production is very high due to unlimited access to nitrogen. In nature, in optimal conditions, it has a surface-area doubling time of 7-10 days or 2.2-3.4 days under laboratory conditions (Kitoh et al. 1993).

A. filiculoides is the most frost-tolerant of the Azolla species. Janes (1998a) observed successfully overwintered vegetative plants in Worcester (UK), where the minimum air temperature reached $-10^{\circ} \mathrm{C}$. Plants were able to survive for at least one week frozen inside the ice; parts protruded above the ice were killed. Wong et al. (1987) reported that $A$. filiculoides endured field temperatures from -10 to $-15^{\circ} \mathrm{C}$. In sub Mediterranean area Azolla filiculoides is evergreen species.

A. filiculoides settles in sunny to shady parts of ponds, ditches, water reservoirs and slow flowing rivers and channels. Due to its symbiotic association with Anabaena azollae, the fern is able to grow in nitrogen-deficient waters but it prefers mezotrophic to eutrophic habitats, often more or less polluted. As an element of pleuston it occurs in plant communities of the class Lemnetea minoris. The fern is described as a diagnostic species of the class Lemnetea and order Lemnetalia minoris (Pott 1995; Matuszkiewicz 2008), and character species of the association Lemno-Azoletum filiculoidis Br.-B1. 1952 (Otahelová 1995). In some cases the species can be found together with Lemna minuta, Lemna minor and Spirodela polyrhiza. More often A. filiculoides forms dense homogenous mats that can eliminate submerged plants and algae (Janes et al. 1996). This form is described as an aggregation of Azolla filiculoides or a community Lemna minor-Azolla filiculoides (Pott 1995).

\section{MATERIAL AND METHODS}

Phytosociological relevés were made using the cover of every species estimated in \%, what was more precise than the classic Braun-Blanquet method (1964). The phytocoenoses were identified to the plant communities according to Matuszkiewicz (2008). Vascular plants nomenclature used in this study is given after Mirek et al. (2002).

The map of plant distribution was generated using the GNOMON software and prepared in $10 \times 10 \mathrm{~km}$ squares of the ATPOL grid (Zając 1978).

\section{THE DISTRIBUTION IN POLAND}

The first data on Azolla filiculoides in Poland come from the beginning of the 20th century. Schube (1928) observed the species in the palace park in Wawrzyszewo (Lower Silesia, south-western Poland), and the palace owners confirmed that Azolla wintered there for several years. Moreover, Schube (1928) informed about cultivation of this species in the Botanical Garden of the University of Wrocław. Rostański and Sowa (1986-1987) included Azolla filiculoides into the list of Polish efemerophytes. After 1945 Azolla was noticed in 1996 in Bielsk Podlaski (Podlasie, north-eastern Poland) but it was a one-season stand only (Wołkowycki 1999).

Since 1996 Azolla filiculoides has been found in five locations in Lower Silesia. It was observed in anthropogenic 
ponds as well as in oxbow lakes, but always in eutrophic water. It appeared in the anthropogenic pond in Wilkszyn near Wrocław and in the oxbow lake of Nysa Łużycka near Koźlice (Fig. 1). These two locations were found in 2007 and still exist. Three other stands were noted in Wrocław. Location in the small pond in the Odra River valley in Popowice was observed in 1996 (Panek, personal inf.) and was destroyed during building of the sport center. Location in the fire-protection pond in Pilczyce was observed in the same year (Nawara, personal inf.) and was destroyed during the long renovation of the reservoir. Both stands have not been confirmed since 1998. In 2009 only one location was confirmed, found in 2007 in the oxbow lake of the Odra River in Kozanów.

In Poland, Azolla filiculoides stays sterile and propagates only vegetatively yet. The size of population is changeable during the vegetation season. Single floating plants emerge at the beginning of summer, the number of ferns increases in summer, and Azolla dominates on the water surface in autumn. In Wilkszyn and Kozanów, in November 2007 and 2008 Azolla formed $10 \mathrm{~cm}$ thick mats and covered all the water surface (Fig. 2). The cover of Azolla was very dense and eliminated all native floating plants.

In Lower Silesia, Azolla filiculoides formed its own community or co-dominated in Lemna minor-Azolla filiculoides community. Moreover, it entered all floating or rush plant communities in colonized ponds; it was observed in community of Nuphar luteum and of Stratiotes aloides, and in associations of Typhetum latifoliae Soó 1927 or Phragmitetum australis (Gams 1927) Schmale 1939 (Table 1).
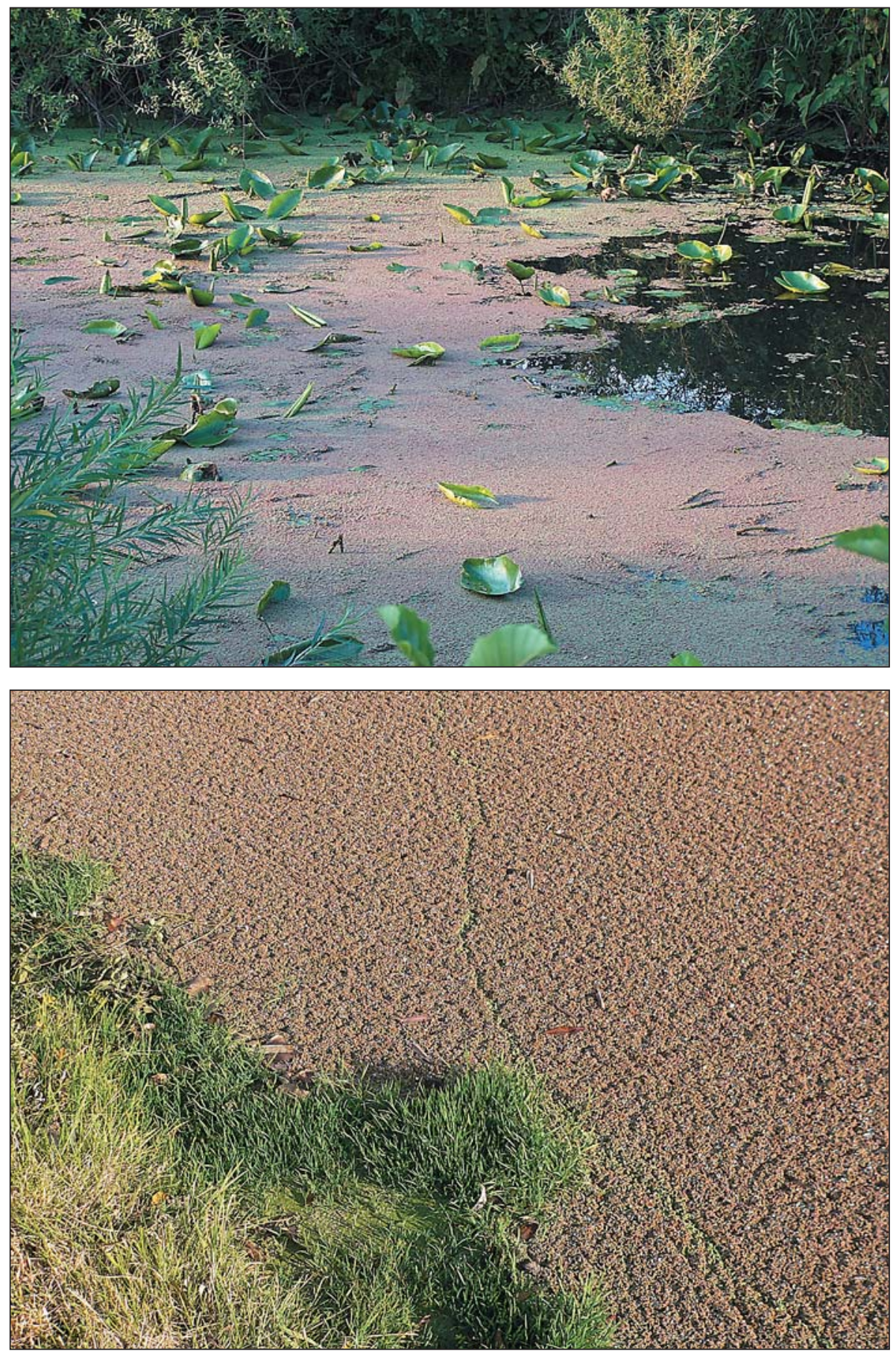

Fig. 1. Azolla filiculoides in the oxbow lake of Nysa Łużycka near Koźlice (phot. J. Błachuta).
Fig. 2. Dense mat of Azolla filiculoides in the old fire protection pond in Wilkszyn village (phot. E. Szczęśniak). 
TABLE 1. Plant communities with Azolla filiculoides Lam. in Poland.

\begin{tabular}{|c|c|c|c|c|c|c|c|}
\hline Succesive number & 1 & 2 & 3 & 4 & 5 & 6 & 7 \\
\hline Date & $\begin{array}{c}2008 . \\
10\end{array}$ & $\begin{array}{c}2008 . \\
08\end{array}$ & $\begin{array}{c}2008 \\
10\end{array}$ & $\begin{array}{c}2008 . \\
10\end{array}$ & $\begin{array}{c}2008 . \\
10\end{array}$ & $\begin{array}{c}2008 . \\
10\end{array}$ & $\begin{array}{c}2008 . \\
10\end{array}$ \\
\hline Area $\mathrm{m}^{2}$ & 20 & 20 & 20 & 20 & 20 & 15 & 20 \\
\hline Cover of herb layer [\%] & 100 & 100 & 100 & 100 & 100 & 100 & 90 \\
\hline Localization & 1 & 1 & 3 & 2 & 3 & 2 & 2 \\
\hline No. of species & 1 & 2 & 6 & 4 & 5 & 8 & 8 \\
\hline
\end{tabular}

\section{Ch. Cl. Lemnetea minoris}

Azolla filiculoides

100

Lemna minor

Ch.Cl. Potametea

Nuphar luteum

Stratiotes aloidis

Elodea canadensis

Ceratophyllum demersum

Hydrocharis morsus-ranae

Ch.Cl. Phragmitetea

Typha latifolia

Phragmites australis

Alisma plantago-aquatica

Sagittaria sagitifolia

Galium palustre

Carex gracilis

Accompanying species

Leersia oryzoides

Juncus effusus

Calystegia sepium

Leonurus cardiaca

\begin{tabular}{lrrr}
50 & 50 & 50 & 50 \\
\hline 50 & + & + & + \\
& & & \\
. & 50 &. &. \\
. &. & 50 & 40 \\
. & + &. & + \\
. & + &. &. \\
. & + &. &.
\end{tabular}

Location of relevés: 1,2 - Wilkszyn, 3 - Koźlice, 4, 5, 6, 7 - Wrocław-Kozanów

List and map of localities in Poland (Fig. 3)

GC51: Bielsk Podlaski (Wołkowycki 1999), 1.n.c.;

AE44: Koźlice, oxbow lake of Nysa Łużycka; Błachuta, Picińska-Fałtynowicz 2007, Krukowski 2008;

BE38: Wilkszyn, old fire-protection pond; Krukowski 2007, Szczęśniak 2007-2009, leg. Szczęśniak 2008 WRSL;

BE48: Popowice, small pond near Odra River; Panek E. 1997, personal information, 1.n.c. - pond destroyed during sport center building; Kozanów, oxbow lake of Odra River; Pender 2007, personal information, Szczęśniak 2007-2009, leg. Szczęśniak 2008 WRSL; Pilczyce, industrial fire pond, Nawara Z. 1996, personal information, 1.n.c. - population destroyed during pond renovation;

CE80: Wawrzyszewo, pond in a palace park (Schube 1928), 1.n.c. - pond destroyed after 1945.

\section{DISCUSSION}

Species of Azolla are the only ferns of high economical value. Because of the ability for atmospheric nitrogen assimilation, quick growth and high content of readily available proteins, Azolla is used as a green manure in rice fields to fertilize the soil. Reyes and Fermin (2003), described the use of Azolla as a feed for fish. Moreover, a dense mat of Azolla stops the growth of weeds and insect larvae. It is the source of its common name "the mosquito fern".

Advantages in cultivation become disadvantages, when Azolla penetrates natural ecosystems. Dense mats of floa-

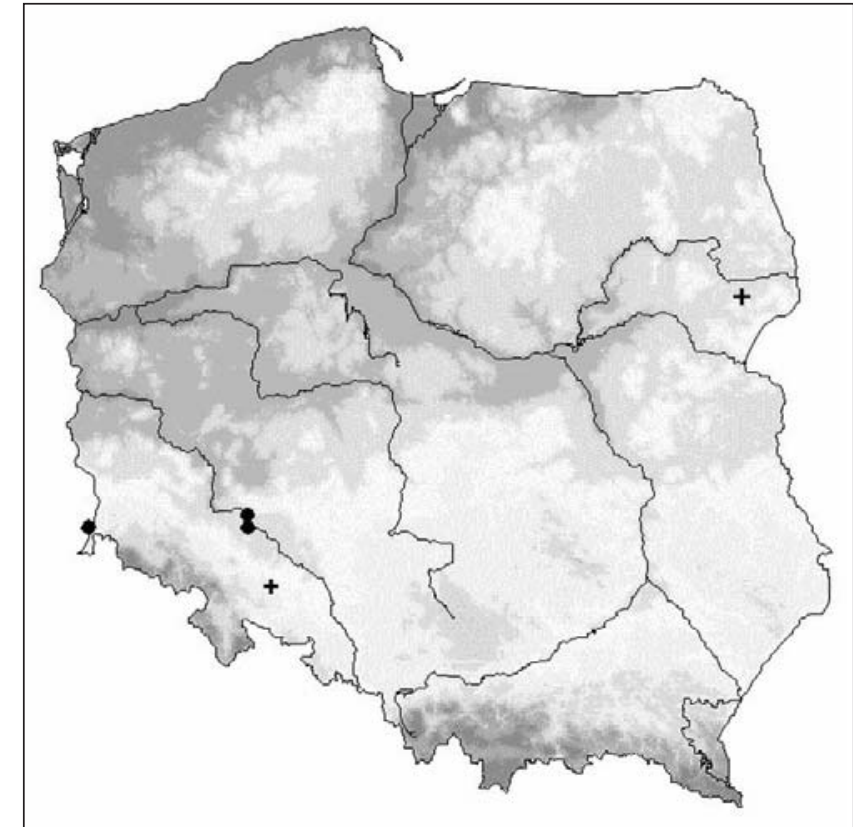

Fig. 3. Distribution of Azolla filiculoides in Poland.

- locations observed in 2007-2009; + - locations not confirmed

ting Azolla can affect the ecosystem by substituting native floating species, preventing their photosynthesis and blocking oxygen diffusion (Janes et al. 1996). Populations of water animals are also reduced beneath the fern mats (Gratwicke and Marshall 2001). 
A. filiculoides has no economic value in Poland and it is still found in a few localities only. It is uncertain if its occurrence in these stands is established or only accidental, but climate changes taking place in the last decades support the theory of this species expansion. Moreover, observations in winter 2007/2008 and 2008/2009 show the growth of the Azolla filiculoides frost resistance. Populations of Lower Silesia seem to be able to survive frost reaching $-22^{\circ} \mathrm{C}$. Almost all individuals on the open water surface were frozen but buds of plants hidden between rushes survived the winter, renewing their growth in next season and rebuilding a dense mat.

It is difficult to say how the new stands in Poland were established. Ferns beginning the population in Koźlice could be transported by birds but other locations situated in towns and villages seem to be anthropogenic in origin. Undoubtedly the stand in Wilkszyn is anthropogenic, where Azolla spread out after uncontrolled introduction of fish. Moreover, aquarium keepers and their enthusiasm for increasing of biodiversity and alien species introduction may play an important role in spread of this species. Rune and Jorgensen (1997) gave examples of intentional releases of A. filiculoides plants in Denmark.

The control of $A$. filiculoides expansion is limited. Due to extremely short time of 3-10 days of a surface-area doubling, the mechanical control requires frequent repetitions and can be effective only in small water bodies. More effective forms of Azolla control are herbicides (diquat or glyphosate). Nevertheless, Hill and Cilliers (1999) considered the manual, mechanical and herbicidal control as insufficient. Barreto et al. (2000) described the biological control of Azolla with fungi. Hill (1998), Hill and Cilliers (1999) and McConnachie et al. (2003, 2004) gave examples of successful biological control of fern massive occurrences by the frond-feeding weevil Stenopelmus rufinasus in South Africa, which is however useless in cold climate of Poland.

An attempt to eliminate Azolla filiculoides took place in Wilkszyn in late autumn 2007. The fern was mechanically removed from the water surface and taken away by six trailers. In spite of the apparent pond clearing, the population rebuilt in 2008. A. filiculoides is potentially an invasive species and could become a substantial problem in fishponds in south and western parts of the country (Szczęśniak 2008).

\section{LITERATURE CITED}

BRAUN-BLANQUET J. 1964. Pflanzensoziologie. Grundzüge der Vegetationskunde. 865 pp. Springer Verlag. Wien, New Jork.

BARETTO R., CHARUDATTAN R., POMELLA A., HANADA R. 2000. Biological control of neotropical aquatic weeds with fungi. Crop Prot. 19: 697-703.

CARRAPIÇO F. 1991. Are bacteria the third partner of the Azolla-Anabaena symbiosis? Plant and Soil 137(1): 157-160.

CARRAPIÇO F. 2006. Is the Azolla-Anabaena symbiosis a coevolution case? In: Sitnykov A. (ed.), General Botany: Traditions and Perspectives. Mat. of the International Conf. dedicated to 200th anniversary of the Kazan Botanical School. Part. I. 193-195.

EVRARD C., HOVE van C. 2004. Taxonomy of the American Azolla species (Azollaceae): a critical reviev. Syst. and Geogr. Pl. 74: 301-318.
GRATWICKE B., MARSHALL B.E. 2001. The impact of Azolla filiculoides Lam. on animal biodiversity in streams in Zimbabwe. Afr. J. Ecol. 39, 216-218.

GUDŽINSKAS Z. 2000. Conspectus of alien plant species of Lithuania. 15. Azollaceae, Pinaceae, and Salicaceae. Bot. Lithuan. 6(3): 235-242.

HILL. M.P. 1998. Life history and laboratory host range of Stenopelmus rufinasus, a natural enemy for Azolla filiculoides in South Africa. BioControl 43: 215-224.

HILL M.P., CILLIERS C.J. 1999. Azolla filiculoides Lamarck (Pteridophyta: Azollaceae), its status in South Africa and control. Hydrobiol. 415: 203-206.

HOVE van C., LEJEUNE A. 2002. The Azolla-Anabaena symbiosis. Biology and Environment: Proc. R. Irish Acad., Vol. 102B(1): 23-26.

HRIVNÁK R., OTAHEL'OVÁ H., RYDLO J., KOCHJAROVÁ J. 2007. Aktuálne údaje o výskyte niektorých vodných rastlín z územia slovenska. Bulletin Slovenskej botanickej spoločnosti. 29: 68-78. (in Slovakian)

HUSSNER A. 2006. NOBANIS - Invasive Alien Species Fact Sheet - Azolla filiculoides. - From: Online Database of the North European and Baltic Network on Invasive Alien Species - NOBANIS www.nobanis.org

JANCZYK-KOPIKOWA Z. 1977. Flora of the Pleistocene. In: Ruhle E. (ed.), Geology of Poland II. Catalogue of fossils. 3b. Cainozoic, Quaternary. pp. 43-70. Wyd. Geologiczne, Warszawa.

JANES R. 1998a. Growth and survival of Azolla filiculoides in Britain. 1. Vegetative reproduction. New Phytol. 138: 367$-376$.

JANES R. 1998b, Growth and survival of Azolla filiculoides in Britain. 2. Sexual reproduction. New Phytol. 138: 377-384.

JANES R., EATON, J.W., HARDWICK K. 1996. The effects of floating mats of Azolla filiculoides Lam. and Lemna minuta Kunth on the groth of submerged macrophytes. Hydrobiol. 340: 23-26.

KITOH S., SHIOMI N. UHEDA E. 1993. The growth and nitrogen fixation of Azolla filiculoides Lam. in polluted water. Aquat. Bot. 46: 129-139.

KUBÁT K. 2002. Azollaceae. In: Kubát K. (ed.), Klíč ke květeně České republiky. Academia, Praha. (in Czech)

LUMPKIN T.A. 1993. Azollaceae Wettstein. In: Flora of North America, vol. 2. New York and Oxford. http:// www.efloras.org

LUMPKIN T.A., PLUCKNETT D.L. 1980. Azolla: Botany, Physiology, and Use as a Green Manure. Econ. Bot. 34 (2): 111-153.

MATUSZKIEWICZ W. 2008. Przewodnik do oznaczania zbiorowisk roślinnych Polski. Vademecum Geobotanicum 3. Wyd. Nauk. PWN, Warszawa. (in Polish)

McCONNACHIE, A.J., WIT, M.P. DE, HILL, M.P., BYRNE, M.J. 2003. Economic evaluation of the successful biological control of Azolla filiculoides in South Africa. Biol. Control 28: 25-32.

McCONNACHIE, A.J., HILL, M.P., BYRNE, M.J. 2004. Field assesment of a frond-feeding weevil, a succesful biological control of Azolla filiculoides in South Africa. Biol. Control 29: 326-331.

MIREK Z., PIĘKOŚ-MIREK H., ZAJĄC A., ZAJĄC M. 2002. Flowering plants and pteridophytes of Poland. A checklist. Biodiversity of Poland. 1. W. Szafer Institute of Botany, Polish Academy of Sciences, Kraków.

OTAHELOVÁ H. 1995. Lemnetea. In: Valachovič M. (ed.), Rastlinné spoločenstvá Slovenska. 1. Pionierska vegetácia. VEDA, Vydavatelstvo Slovenskej Akadémie Vied, Bratyslava. 131-152. (in Slovakian)

POTT R. 1995. Die Pflanzengesellschaften Deutschlands. Verlag Eugen Ulmer, Stuttgart.

RANIECKA-BOBOWSKA J. 1977. Flora of the Palaeogene and Neogene. Macroflora. In: Ruhle E. (ed.), Geology of Poland II. 
Catalogue of fossils. 3a. Cainozoic, Tertiary. Wyd. Geologiczne, Warszawa, pp. 161-216.

REYES O.S., FERMIN A.C. 2003. Terrestrial leaf meals or freshwater aquatic fern as potential feed ingredients for farmed abalone Haliotis asinine (Linnaeus 1758). Aquacult. Res. 34 (8): 593-599.

ROSTAŃSKI K., SOWA R. 1986-1987. Alfabetyczny wykaz efemerofitów Polski. Fragm. Flor. Geobot. 31-32(1-2): 151-203. (in Polish)

RUNE F., JORGENSEN H. 1997. Andemadsbregne (Azolla Lamarck) - botanik, udbredelse og anvedelse. URT 2: 59-65. (in Danish)

SCHUBE T. 1928. Ergebnisse der Durchforschung der schlesischen Gefässpflanzenwetl im Jahre 1927. Jahres-Bericht der Schles. Gesselschaft für vaterl.Cultur. 101: 30-37.

SZCZEŚSIAK E. 2008. Endangered, expansive and invasive species in pteridoflora of the Lower Silesia. In: Szczęśniak E., Gola E. (eds), Club-mosses, horsetails and ferns in Poland resources and protection. pp. 213-223. Polish Botanical Society and Institute of Plant Biology, Univesity of Wrocław, Wrocław.

VALENTINE D.H., MOORE D.M. 1993. Azollaceae. In: Tutin T.G., Burges N.A., Chater A.O., Edmondson J. R., Heywood
V. H., Moore D. M., Valentine D. H., Walters S. M., Webb D. A. (eds), Flora Europaea. 1. p. 33. Cambridge Univ. Press, Cambridge.

WATANABE I., BERJA N.S. 1983: The growth of four species of Azolla as affected by temperature. Aquat. Bot. 15: 175-185.

WATANABE, I., HOVE van C. 1996. Phylogenetic, molecular and breeding aspects of Azolla-Anabaena symbiosis. In: J.M. Camus, M. Gibby, R.J. Johns (eds), Pteridology in Perspective. Royal Botanic Gardens, Kew: 611-619.

WEBER E. 2005. Invasive Plant Species of the World. CABI Publishing, 548 pp.

WILMANNS O. 1976. Die Farnpflanzen Zentraleuropas. Gustav Fischer Verlag, Suttgart. 304 pp.

WOŁKOWYCKI D. 1999. Azolla filiculoides (Pteridophyta, Azollaceae) w Polsce. Fragm. Flor. Geobot. Ser. Polonica 6: 165-170. (in Polish)

WONG FONG SANG H.W., VU VAN VU, KIJNE J.W., VU T.T., PLANQUE K. 1987. Use of Azolla as a test organism in a growth chamber of simple design. Plant and Soil 99: 219-230 .

ZAJAC A. 1978. Atlas of distribution of vascular plants in Poland. Taxon 27(5-6): 481-484. 